Fernanda Meira ${ }^{1}$

Laia Albiach ${ }^{1}$

Cristina Carbonell ${ }^{2}$

José-Ángel Martín-Oterino

Mercedes Martín-Ordiales ${ }^{2}$

Laura Linares ${ }^{1}$

Irene Macaya ${ }^{1}$

Daiana Agüero ${ }^{1}$

Juan Ambrosioni ${ }^{1}$

Marta Bodro ${ }^{1}$

Celia Cardozo ${ }^{1}$

Mariana Chumbita ${ }^{1}$

Lorena De la Mora ${ }^{1}$

Nicole García-Pouton ${ }^{1}$

Carolina Garcia-Vidal ${ }^{1}$

Ana González-Cordón ${ }^{1}$

Marta Hernández-Meneses ${ }^{1}$

Alexy Inciarte ${ }^{1}$

Montserrat Laguno ${ }^{1}$

Lorna Leal ${ }^{1}$

Laura Morata ${ }^{1}$

Pedro Puerta-Alcalde ${ }^{1}$

Verónica Rico ${ }^{1}$

Laura Letona ${ }^{1}$

Alberto Cózar-Llistó

Gerard Dueñas ${ }^{1}$

Montserrat Solá

Berta Torres ${ }^{1}$

Jhon Rojas ${ }^{1}$

Antonio Moreno ${ }^{1}$

Estela Moreno-García ${ }^{1}$

Manuel Torres ${ }^{1}$

José A Martínez ${ }^{1}$

Alex Soriano ${ }^{1}$

Felipe García ${ }^{1}$

\section{Experience with the use of siltuximab in patients with SARS-CoV-2 infection}

'Department of Infectious Diseases, Hospital Clinic of Barcelona, Barcelona, Spain.

${ }^{2}$ Department of Internal Medicine, University Hospital of Salamanca-IBSAL. Salamanca, Spain.
Article history

Received: 25 March 2021; Accepted: 4 May 2021; Published: 13 May 2021

\section{ABSTRACT}

Objectives. The study aims to describe characteristics and clinical outcome of patients with SARS-CoV-2 infection that received siltuximab according to a protocol that aimed to early block the activity of IL-6 to avoid the progression of the inflammatory flare.

Patients and methods. Retrospective review of the first 31 patients with SARS-CoV-2 treated with siltuximab, in Hospital Clinic of Barcelona or Hospital Universitario Salamanca, from March to April 2020 with positive polymerase-chain reaction (PCR) from a nasopharyngeal swab.

Results. The cohort included 31 cases that received sil- tuximab with a median (IOR) age of 62 (56-71) and 71\% were males. The most frequent comorbidity was hypertension (48\%). The median dose of siltuximab was $800 \mathrm{mg}$ ranging between 785 and $900 \mathrm{mg} .7$ patients received siltuximab as a salvage therapy after one dose of tocilizumab. At the end of the study, a total of 26 (83.9) patients had been discharged alive and the mortality rate was $16.1 \%$ but only 1 out of 24 that received siltuximab as a first line option (4\%).

Conclusions. Siltuximab is a well-tolerated alternative to tocilizumab when administered as a first line option in patients with COVID-19 pneumonia within the first 10 days from symptoms onset and high C-reactive protein.

Keywords: IL-6; siltuximab; COVID-19 mortality. 


\section{Experiencia con el uso de siltuximab en pacientes con infección por SARS-CoV-2}

\section{RESUMEN}

Objetivo. Nuestro estudio tiene como objetivo describir las características clínicas y evolución de los pacientes infectados por SARS-CoV-2 tratados con siltuximab, de acuerdo con el protocolo local, con objetivo de bloquear precozmente la actividad de la Interleukina-6 evitando la progresión de la cascada inflamatoria.

Pacientes y métodos. Estudio retrospectivo de los primeros 31 pacientes con COVID-19 tratados con siltuximab en el Hospital Clínic de Barcelona y en el Hospital Universitario de Salamanca, en el periodo de marzo a abril, que tenían una PCR en frotis nasal positiva para SARS-CoV-2.

Resultados. Fueron incluidos 31 pacientes tratados con siltuximab, con una mediana (RIC) de edad de 62 años (56-71) y una prevalencia de varones del 71\%. La comorbilidad más frecuente fue la hipertensión arterial (48\%). La mediana de dosis administrada de siltuximab fue $800 \mathrm{mg}$ con un rango de $785 \mathrm{mg}$ a $900 \mathrm{mg}$. Siete pacientes recibieron siltuximab como terapia de rescate después de una dosis de tocilizumab. Al final del estudio, un total de 26 (83.9) pacientes recibieron alta hospitalaria vivos. La tasa de mortalidad fue de 16.1\%, sin embargo, solo 1 de los 24 pacientes que recibieron siltuximab como primera línea de tratamiento falleció (4\%).

Conclusiones. Siltuximab es una alternativa bien tolerada al uso de tocilizumab como primera línea de tratamiento para pacientes con neumonía por COVID-19 dentro de los primeros 10 días de sintomas y con proteína C-reactiva elevada.

Palabras clave: IL-6; siltuximab; COVID-19, mortalidad.

\section{INTRODUCTION}

Infection by Coronavirus 2 (SARS-CoV-2) emerged in December 2019 in Wuhan and rapidly spread around the world. SARS-CoV-2 is characterized by a high viral replication during the first days associated to a range of clinical manifestations from asymptomatic or mild to classical symptoms including fever, bad general status, myalgia, and cough. More than $80 \%$ of the infected patients have a self-limited infection but 15-20\% develop a severe pneumonia and require hospital admission. In contrast to other respiratory virus bacterial co-infection is not a major cause of hospitalization, but it is characterized by a progressive respiratory failure, and bilateral infiltrates in the $X$-ray that resembles an adult distress respiratory syndrome (ARDS) [1]. This clinical pattern associated with severe lymphopenia and high C-reactive protein (CRP) and other raised inflammatory parameters suggests that this corresponds with the cytokine release syndrome (CRS) [2].

Interleukin-6 (IL-6) plays an important role in CRS, therefore, the inhibition of this cytokine has been proposed as po- tential alternative for severe pneumonia due to SARS-CoV-2 [3]. The first description included 21 patients that were admitted in a Chinese hospital and received tocilizumab, a recombinant humanized anti-human IL-6 receptor monoclonal antibody. In few days, symptoms improved remarkably, in 75.0\% of patients lowering of their oxygen intake was possible and no patient died. Currently, there is experience with tocilizumab in randomized trials $[4,5]$. No one of these studies have demonstrated a reduction in the mortality rate among those receiving the anti-IL-6 therapy but they were not powered enough to detect differences in mortality and at least in one of them there was a significant reduction in the intensive care unit (ICU) admission among those receiving tocilizumab [6]. Siltuximab is a chimeric monoclonal antibody that binds to and neutralizes the effect of IL-6 [7] instead of blocking the IL-6 receptor. A study from Italy evaluated siltuximab in 30 patients that were matched to 30 control patients using the propensity score analysis of baseline covariates. The 30-day mortality rate was significantly lower in the siltuximab-treated than the matched-control cohort patients (HR 0.462, 95\% Cl 0.221-0.965); $p=0 \cdot 0399)$. Sixteen siltuximab-treated patients were discharged from hospital, four remained on mechanical ventilation, and 10 patients died. However, this article is included in a repository and it is not yet peer reviewed.

The main objective of the present article is to describe the characteristics and clinical outcome of the first 31 patients in two hospitals with a SARS-CoV-2 infection that received treatment with siltuximab according to a protocol that aimed to early block the activity of IL-6 to avoid the progression of the inflammatory flare.

\section{PATIENTS AND METHODS}

Both Hospitals ethical committees approved the study. The Institutional Ethics Committee of the Hospital Clinic of Barcelona approved the study and due to the nature of retrospective chart review, waived the need for inform consent from individual patients (HCB/2020/0273).

Patients admitted to Hospital Clinic of Barcelona or Hospital Universitario Salamanca, from March to April 2020 with a positive polymerase-chain reaction (PCR) from a nasopharyngeal swab or fulfilling the clinical diagnostic criteria for SARSCoV-2 and treated with siltuximab were retrospectively reviewed.

The criteria for hospital admission were similar in both hospitals, including patients with respiratory symptoms and pneumonia (uni- or bilateral interstitial infiltrates) as indicated by the chest X-ray. For ARDS, the Berlin definition [8] was applied. When arterial blood oxygen pressure $\left(\mathrm{PaO}_{2}\right)$ was not available, the ratio between the percentage of oxygen saturation by fraction of oxygen inspired $\left(\mathrm{SpO}_{2} / \mathrm{FiO}_{2}\right) \leq 315$ suggested ARDS in non-ventilated patients [9]. The antiviral treatment was initiated to all patients and consisted of lopinavir/ritonavir 400/100 mg twice a day for 7-14 days plus hydroxychloroquine $400 \mathrm{mg} / 12 \mathrm{~h}$ on the first day, followed by $200 \mathrm{mg} / 12 \mathrm{~h}$ for 


\begin{tabular}{|c|c|c|}
\hline Table 1 & \multicolumn{2}{|l|}{ Baseline characteristics. } \\
\hline Study popul & & $N(\%)$ \\
\hline $\mathrm{N}^{0}$ of patien & & 31 \\
\hline Age, median & jears & $62(56-71)$ \\
\hline Male sex $(\%$ & & $22(71)$ \\
\hline Median follc & days (IOR) & $14(9-20)$ \\
\hline \multicolumn{3}{|c|}{ Comorbidities } \\
\hline Hyperten & & $15(48.4)$ \\
\hline Dyslipida & & $11(35.5)$ \\
\hline Cardiom & & $4(12.9)$ \\
\hline Chronic r & ory disease & $4(12.9)$ \\
\hline Diabetes & & $3(9.7)$ \\
\hline Chronic & isease & $4(12.9)$ \\
\hline \multicolumn{3}{|c|}{ Initial symptoms } \\
\hline Fever & & $30(96.8)$ \\
\hline Cough & & $23(74.2)$ \\
\hline Dyspnoe & & $14(45.2)$ \\
\hline Median day & ymptom onset until admission (IQR) & $7(5-10)$ \\
\hline Median day & dmission to siltuximab administration (IOR) & $2(1-4)$ \\
\hline Siltuximab a & ration in the regular ward $(\%)$ & $25(80.6)$ \\
\hline Siltuximab a & ration in the ICU (\%) & $6(19.4)$ \\
\hline ARDS at hos & mission $(\%)$ & $12(38.7)$ \\
\hline \multicolumn{3}{|c|}{ In hospital complications } \\
\hline Acute res & re without dialysis & $5(16)$ \\
\hline Thrombo & & $2(6.5)$ \\
\hline ARDS du & pitalization & $13(41.9)$ \\
\hline Nosocom & ctions & $7(22.6)$ \\
\hline Urinary $t$ & ection & $3(9.7)$ \\
\hline Catheter & ted infection & $3(9.7)$ \\
\hline Not iden & & $1(3.2)$ \\
\hline \multicolumn{3}{|c|}{ Clinical outcomes $(\%)$} \\
\hline ICU admi & global cohort & $11(35.5)$ \\
\hline ICU admi & 25 patients receiving siltuximab at general ward & $5(16.1)$ \\
\hline \multicolumn{3}{|c|}{ Mechanical ventilation } \\
\hline Non-inva & & $9(29)$ \\
\hline Invasive & & $6(19.4)$ \\
\hline ICU discharo & & $9(81.8)$ \\
\hline In-hospital । & $y(\%)$ & $5(16.1)$ \\
\hline
\end{tabular}

$\mathrm{ICU}$, intensive care unit. ADRS, acute distress respiratory syndrome. the next 4 days. From 18th of March, azithromycin $500 \mathrm{mg}$ the first day and $250 \mathrm{mg} / 24 \mathrm{~h}$ for 4 additional days was added to the regimen. The indication of an IL-6 inhibitor was the presence of pneumonia and progressive respiratory failure defined as the need of increasing the $\mathrm{FiO}_{2}$ and a $\mathrm{CRP} \geq 7 \mathrm{mg} / \mathrm{dL}$ or ferritin $\geq 800 \mathrm{ng} / \mathrm{mL}$ or lymphocyte count $<800$ cells $/ \mathrm{mm}^{3}$. The first line option was tocilizumab but during the pandemic period the availability was limited and the alternative we chose was siltuximab. The dose was $11 \mathrm{mg} / \mathrm{kg}$ and a second dose could be administered at the physician's discretion. Siltuximab, in the majority of the cases presented in this report, was the first-line option but in some of them it was administered 24-48h after the first dose of tocilizumab due to non-adequate response (salvage therapy). The outcomes of the present study include intensive care unit (ICU) admission (for those patients that received siltuximab at the general ward), need of mechanical ventilation, in-hospital mortality rate and other complications including pulmonary embolisms and nosocomial infections.

Categorical variables were described using the absolute number and percentage and continuous variables using the median and interquartile range (IOR). The analysis was performed in SPSS version 23 (SPSS Inc., Chicago, IL).

\section{RESULTS}

The cohort included 31 cases that received siltuximab with a median (IOR) age of 62 (56-71) and $71 \%$ were males. The most frequent comorbidities were hypertension (48\%), dyslipidaemia (35.5\%), cardiomyopathy (12.9\%), chronic respiratory disease (12.9\%), chronic kidney disease (12.9\%), and diabetes (9.7\%). The median days from symptoms onset to hospital admission were 7 ranging from 5 to 10 days. Fever was a presenting symptom in $96.8 \%$ of patients, 74\% also reported dry cough and 45.2\% reported dyspnoea at hospital admission (table 1 ). Twenty-five (80.6\%) patients had ARDS, 12 at hospital admission and 13 during hospital admission. ARDS was mild in 13 (41.9\%) patients, moderate in 11 (35.5\%), and severe in 1 (3.2\%). All patients had a positive PCR from a nasopharyngeal swab and unilateral or bilateral interstitial infiltrate in the chest-X ray. Main laboratory findings at hospital admission are shown in table 2.

The median dose was siltuximab was $800 \mathrm{mg}$ ranging between 785 and $900 \mathrm{mg}$. All patients received as antiviral treatment lopinavir/ritonavir plus hydroxychloroquine. Azithromycin was administered for 26 (83.9\%) patients and 5 patients received remdesivir. As for other interleukin inhibitors, 8 patients also received tocilizumab and 6 anakinra. Eighteen 


\begin{tabular}{l|c}
\hline Table 2 & $\begin{array}{l}\text { Laboratory findings at hospital } \\
\text { admission. }\end{array}$ \\
\hline Laboratory findings, Median (IOR) & $\mathrm{N}(\%)$ \\
\hline D-dimer $(\mathrm{ng} / \mathrm{mL})^{\mathrm{a}}$ & $800(425-1,025)$ \\
Lymphocytes count $\left(\mathrm{cell} / \mathrm{mm}^{3}\right)$ & $900(700-1,100)$ \\
C-reactive protein $(\mathrm{mg} / \mathrm{dL})$ & $9.78(5.09-24.64)$ \\
Ferritin $(\mathrm{ng} / \mathrm{mL})^{\mathrm{b}}$ & $1,772(971-2,204)$ \\
Lactate dehydrogenase $(\mathrm{U} / \mathrm{L})$ & $346(287-427)$ \\
\hline
\end{tabular}

${ }^{\mathrm{a}}$ Measured in 30 cases; $^{\mathrm{b}}$ Measured in 19 cases

\section{Table 3 Additional antiviral and anti- inflammatory treatments.}

\begin{tabular}{lc}
\hline Treatments received (\%) & $\mathrm{N}(\%)$ \\
\hline Hydroxychloroquine & $31(100)$ \\
\hline Lopinavir/ritonavir & $31(100)$ \\
\hline Azithromycin & $26(83.9)$ \\
\hline Remdesivir & $5(16.1)$ \\
\hline Interferon & $1(3.2)$ \\
\hline Steroid therapy & $18(58.1)$ \\
\hline Steroid therapy prior to siltuximab & $11(35.5)$ \\
\hline Tocilizumab & $8(25.8)$ \\
\hline Tocilizumab prior to siltuximab & $7(22.58)$ \\
\hline Days from tocilizumab administration to siltuximab (IOR) & $2(1-3)$ \\
\hline Anakinra & $7(22.6)$ \\
\hline Anakinra after siltuximab administration & $6(19.4)$ \\
\hline
\end{tabular}

patients $(58.1 \%)$ received steroid therapy, 11 before siltuximab, 6 after, and 1 the same day (table 3).

Of the 25 patients that received siltuximab at a regular ward, 5 (16\%) required intensive care unit (ICU) admission while 6 patients received siltuximab already in the ICU. Out of these 11 patients that required ICU admission, 6 required invasive mechanical ventilation (table 1). At the moment of the last revision, 26 (83.9) patients had been discharged alive and the mortality rate was $16.1 \%$ (5 patients). The mortality rate among the 7 patients that received siltuximab as a salvage therapy after tocilizumab was $43 \%$ ( 3 out of 7 ). On the other hand, only one patient out of 24 that received siltuximab as a first line option died (4\%). Other clinical complications during admission included: thrombosis in 2 patients (one had a pulmonary embolism), 5 presented acute renal failure without need for dialysis, and 7 (22.6\%) developed nosocomial infections during hospital admission, 3 a urinary tract infection and 3 a catheter-related bacteraemia (table 1).

\section{DISCUSSION}

Monoclonal antibodies directed against key inflammatory cytokines represent a class of adjunctive therapies for SARS-CoV-2 infected patients. The rationale for their use is that the underlying pathophysiology of significant organ damage in the lungs is caused by a cytokine storm being IL-6 one of the key drivers. Therefore, monoclonal antibodies against IL-6 could theoretically improve clinical outcome. Many observational studies have demonstrated a potential efficacy of blocking the IL-6 pathway mainly using tocilizumab $[10,11]$, in contrast, randomized trials have shown negative results in terms of reduction of mortality, but one has demonstrated a reduction in the risk of ICU admission [6]. Siltuximab was administrated to 31 patients with severe COVID-19 and the results when it is administered as a first line option are similar to those reported in our cohort using tocilizumab in the same indication [12]. As it would be expected, those patients that received siltuximab as a salvage therapy had a significantly worse outcome. Considering the mechanism of action of monoclonal antibodies, now it seems not reasonable to use it as a salvage therapy and when the patient is not responding to the IL-6 inhibition, probably these patients are not responding to IL-6 inhibition due to a different pathogenic mechanism that requires further investigation including co-bacterial infection, thrombosis or macrophage activation syndrome that require different treatment approaches.

In conclusion, siltuximab is a well-tolerated alternative to tocilizumab when administered as a first line option in patients with COVID-19 pneumonia within the first 10 days from symptoms onset and high C-reactive protein. In the future, it is necessary to better define the characteristics of patients that benefit from IL-6 inhibition as well as the precise timing of its administration.

\section{ACKNOWLEDGEMENTS}

Hospital Clinic of Barcelona COVID-19 research team:

Department of Infectious Diseases: Blanco JL, Mallolas J, Martínez E, Martínez M, Miró JM, and Moreno A.

Medical Intensive Care Unit: Adrian Téllez, Sara Fernández, Pedro Castro, Josep M Nicolás, and all the staff members.

Department of International Health: Daniel Camprubi Ferrer, Maria Teresa de Alba, Marc Fernandez, Elisabet Ferrer, Berta Grau, Helena Marti, Magdalena Muelas, Maria Jesus Pinazo, Natalia Rodríguez, Montserrat Roldan, Carme Subira, Isabel Vera, Nana Williams, Alex Almuedo-Riera, Jose Muñoz, and all the staff members.

Department of Internal Medicine: Aldea A, Camafort M, Calvo J, Capdevila A, Cardellach F, Carbonell I, Coloma E, Foncillas $A$, Estruch $R$, Feliu M, Fernández-Solá J, Fuertes I, Gabara C, Grafia I, Ladino A, López-Alfaro R, López-Soto A, Masanés F, Matas A, Navarro M, Marco-Hernández J, Miguel L, Milisenda J, Moreno P, Naval J, Nicolás D, Oberoi H, Padrosa J, Prieto-González S, Pellicé M, Ribot J, Rodríguez-Núnez 0, Sacanella E, Se- 
gui $F$, Sierra $C$, Tomé $A$, Ugarte $A$, Ventosa $H$, Zamora-Martínez $\mathrm{C}$, and all the staff members.

Department of Microbiology: M. Almela, M. Alvarez, J. Bosch, C. Casals, J. Costa, G. Cuesta, M. Fernandez, B. Fidalgo, J. Gonzàlez, J.C. Hurtado, F. Marco, M.A. Marcos, M. Martínez, M. Mosquera, S. Narvaez, C. Pitart, E. Rubio, A. Vergara, M.E.Valls, J. Vila, Y. Zboromyrska and all the staff members.

Department of Farmacy: E. López, D. Soy, M. Tuset and all the staff members.

Department of Internal Medicine, University Hospital of Salamanca research team: José Ignacio Martín González, Noelia Cubino Bóveda, Gloria Alonso Claudio, Maite Moreiro Barroso, Maria Luisa Pérez García, José Ignacio Madruga Martín, Catalina Lorenzo, Pepa García Rodríguez, Miguel Marcos Martín, José Ignacio Herrero Herrero, Adela Carpio , Ángela Romero Alegría, Nora Gutiérrez San Pedro, Sandra Inés Revuelta, Leticia Moralejo Alonso, Antonio Chamorro Martín, Celestino Martín Álvarez, Guillermo Hernández, Amparo López Bernús, Maria Sánchez Ledesma, Moncef Belhassen García, Ma Jose Sánchez Crespo, Felipe Álvarez Navia, Patricia Araoz Sánchez, Judit Aparicio García , Jacinto Herráez, David Polo, Ronald Macías, Alejandro Rolo, Juan Francisco Soto, Laura Manzanedo , Luis Seisdedos, Juan Miguel Manrique, Alfredo Javier Collado, Sonia Peña, Sandra Rodríguez, Ana Rodriguez, Silvia Ojea, Laura Burgos, Carlos Reina, Eugenia López, Beatriz Rodríguez

\section{FUNDING}

This research is part of an activity that has received funding from EUSA Pharma for the present study, the research group has received a grant from crowdfunding organized by Hospital Clinic and IDIBAPS. No funding bodies had any role in study design, data collection and analysis, decision to publish or preparation of the manuscript.

\section{CONFLICTS OF INTEREST}

AS has received honoraria for lectures and advisory boards for Pfizer, Merck Sharp and Dohme, Menarini, Shionogi, AngeIlini and Gilead. All other authors had no potential conflicts of interest.

\section{REFERENCES}

1. Zhou F, Yu T, Du R, Fan G, Liu Y, Liu Z, et al. Clinical course and risk factors for mortality of adult inpatients with COVID-19 in Wuhan, China: a retrospective cohort study. Lancet. 2020;395: 1054-1062. doi:10.1016/s0140-6736(20)30566-3

2. McGonagle D, Sharif $K$, O'Regan A, Bridgewood C. Interleukin-6 use in COVID-19 pneumonia related macrophage activation syndrome. Autoimmun Rev. 2020;19: 102537. doi:10.1016/j.autrev.2020.102537

3. Moore JB, June CH. Cytokine release syndrome in severe COVID-19. Science. 2020;368: 473-474. doi:10.1126/science.abb8925
4. Stone $J H$, Frigault MJ, Serling-Boyd NJ, Fernandes AD, Harvey $L$, Foulkes AS, et al. Efficacy of Tocilizumab in Patients Hospitalized with Covid-19. New Engl J Med. 2020. doi:10.1056/nejmoa2028836

5. Parr JB. Time to Reassess Tocilizumab's Role in COVID-19 Pneumonia. Jama Intern Med. 2021;181. doi:10.1001/jamainternmed.2020.6557

6. Salama C, Han J, Yau L, Reiss WG, Kramer B, Neidhart JD, et al. Tocilizumab in Patients Hospitalized with Covid-19 Pneumonia. New Engl J Med. 2021. doi:10.1056/nejmoa2030340

7. Gritti G, Raimondi F, Ripamonti D, Riva I, Landi F, Alborghetti $L$, et al. Use of siltuximab in patients with COVID-19 pneumonia requiring ventilatory support. MedRxiv. 2020; 1-17. doi:10.1101/2020.04.01.20048561

8. Force ADT, Ranieri VM, Rubenfeld GD, Thompson BT, Ferguson ND, Caldwell $E_{1}$ et al. Acute Respiratory Distress Syndrome: The Berlin Definition. Jama. 2012;307: 2526-2533. doi:10.1001/ jama.2012.5669

9. Rice TW, Wheeler AP, Bernard GR, Hayden DL, Schoenfeld DA, Ware $L B$, et al. Comparison of the Spo2/Fio2 Ratio and the Pao2/Fio2 Ratio in Patients With Acute Lung Injury or ARDS. Chest. 2007;132: 410-417. doi:10.1378/chest.07-0617

10. Malgie J, Schoones JW, Pijls BG. Decreased mortality in COVID-19 patients treated with Tocilizumab: a rapid systematic review and meta-analysis of observational studies. Clin Infect Dis. 2020; ciaa1445-. doi:10.1093/cid/ciaa1445

11. Gupta S, Wang W, Hayek SS, Chan L, Mathews KS, Melamed ML, et al. Association Between Early Treatment With Tocilizumab and Mortality Among Critically III Patients With COVID-19. Jama Intern Med. 2021;181. doi:10.1001/jamainternmed.2020.6252

12. Moreno-Garcia E, Rico V, Albiach L, Aguero D, Ambrosioni J, Bodro $M$, et al. Tocilizumab is associated with reduced risk of ICU admission and mortality in patients with SARS-CoV-2 infection. medRxiv preprint 2020, doi.org/10.1101/2020.06.05.20113738 